\title{
Oleksandr SHAROV
}

\section{GEOECONOMIC ASPECTS OF THE MONETARY GLOBALIZATION}

\begin{abstract}
Author defines monetary globalization and examines the historical process of spreading money and cash nexus across the globe. It is stated that money developed almost simultaneously in three great civilizations (Europe, India, China), but over time the Hellenistic form of money absorbed and universalized all other forms of money. The author examines in detail the process of distribution of metallic and then credit form of money and their impact on economic globalization. All these processes occurring both in the markets of separate countries or small regions and at the international level (where money started to act as global currency almost immediately after its appearance) constitute the essence of the monetary globalization. The author dwells on the post-Bretton Woods period of development of the World Monetary System, believing that the extensive phase of monetary globalization has come to an end at this stage and its further development will be caused by fundamental qualitative changes.
\end{abstract}

\footnotetext{
(C) Oleksandr Sharov, 2020.
}

Sharov Oleksandr, Doctor of Economic Sciences, Professor, Senior Researcher at Institute for Economics and Forecasting of the National Academy of Sciences of Ukraine, Kyiv, Ukraine. ORCID: 0000-0001- 8460-9996, Email: osharov@niss.gov.ua 


\section{Key words:}

chrimatogenes, globalization, monetary relations, monetary geography, European Monetary System.

JEL: F59; F62; E52; N10.

\section{Problem statement}

The topic of money geography is not new in scientific research. However, most cases view either the geography of historical and architectural sights depicted on the monetary units, or the role of geographical location in the development of monetary and financial institutions. In particular, Ronald Leonard Martin, a Cambridge geography professor, dedicated his research to this underinvestigated topic and creating a new economic geography of money. In his early work, Professor Martin studied the effect of globalisation on the role of geography in finance and staunchly opposed the idea posed by R. O'Brien on «the end of geography». The investment banker is known to have said, "As markets and rules become integrated, the relevance of geography and the need to base decisions on geography will alter and diminish. Money, being fungible, will continue to try to avoid, and will largely succeed in escaping, the confines of the existing geography. ... The closer we get to a global, integrated whole, the closer we get to the end of geography» (O'Brien, 1992, pp. 2-5). Refuting him, R. Martin stated, "global integration does not spell the "end of geography" as far as the overwhelming locational and trading influence of the world's financial centres is concerned» (as cited in Cohen, 1998, p. 20). On the contrary, he argued that location remained key in financial transactions and operation of markets. This topic was also investigated further in the studies conducted with his colleagues on the importance of location for the private (venture) capital market both in Great Britain and Germany (Department of Geography, n.d.).

Monetary geography and finance are also the topic of the specialised textbook edited by Professor R. Martin and his Newcastle University colleague Professor J. Pollard (2017). However, the chapter titles (for example, chapter 2 "On the geography of bubbles and financial crises»; chapter 4 - «The territorial 
governance of the financial industry»; chapter 8 «The geographical network of bank organizations: issues and evidence for Italy», etc.) clearly indicate a financial focus, i.e. monetary geography is considered from institutional and instrumental viewpoints. Even B. Cohen, who coined the term geography of money, implied only the external (currency) aspect of the geographical distribution of money, describing the direction of his research thus, «My starting point is the widespread and growing use of currencies outside their country of origin. My central thesis is that international relations, political as well as economic, are being dramatically reshaped by the increasing interpenetration of national monetary spaces. Market-driven currency competition alters the distribution of resources and power around the globe. It generates mounting tensions and insecurities potential threats to global stability as well as promising opportunities for cooperation.» (Cohen, 1998, p. 3). A similar approach was taken by some researchers of regional monetary systems (Masson \& Pattillo, 2004).

Therefore, speaking of monetary globalization as a process of geographical spread of monetary relations, we use another term - monetary geography. However, it should be noted that this term was introduced to the Ukrainian scientific community by M. Lyzun (2017, p. 49) and its use, it seems, is largely caused by the intricacies of translation from B. Cohen's (1998) «geography of money» into Ukrainian («монетарна географрія» and back. Although M. Lyzun, in fact, considers the term monetary geography more broadly than her foreign counterparts do with geography of money. The concept of monetary geography acquires, due to her differentiated approach, a new meaning. This is no longer just an overview of currency relations in the relevant geographical areas (as do, in particular, P. Masson and C. Pattillo, who also consider monetary geography), but rather, the hierarchical framework of global monetary relations. Therefore, from our point of view, in this sense it would be more appropriate to use the term currency geography (as a narrower one), but since this term is not in use in English, we simply point out a slightly different meaning given to the concept of monetary geography in this article.

\section{Research results}

We interpret globalization as a process of comprehensive universalization of the humanity's living conditions on a global scale set in the conditions of unprecedented ease of local and transcontinental communication. This process encompasses practically all - domestic, cultural, religious, environmental, information, economic, political - aspects of human existence. However, monetary (money) globalization is the trend of money development that spans the entire recorded history, directed towards internationalization and transformation from national into world (global) equivalent of value of all goods, achieved through erasure of borders in the course of money circulation. 
Consideration globalization from a geoeconomic viewpoint, it should be noted that at different stages various models were at the forefront (in other words, acted as drivers for development), including Greco-Roman, Mongolian, Iberian, British, North Atlantic (American), Soviet (Communist), Chinese versions... In this instance, we do not claim to have the full list of such models, but are merely illustrating the involvement of different countries and states in globalisation as more than just components, but as its promoters, thus highlighting the historical and objective nature of globalisation.

This same influence of different regions is apparent when analysing the monetary globalisation. In particular, Asian models (from Asia Minor to China) favour the state control of money. Conversely, Euro-Atlantic models (from John Law to the American free banking) are based on private lending issue of money. A compromise is observed in the British model and its concept of Central Bank, where a private institution is slowly transformed into an important element of the state machine.

All the while, monetary globalisation is covering more and more space and facilitating unification of monetary systems.

\section{Premodern globalisation}

Money emerged in the premodern era of human development and almost immediately became an instrument of establishing economic relations within societies and states, as well as one of the key elements of the globalisation process.

The invention of money is, undoubtedly, among the most important innovations of humanity. However, the question of when and where it appeared first remains unanswered, and in all likelihood will remain so, as for economic history to solve this puzzle, there must be consensus on the interpretation of the term money, as well as written and archaeological proof of such an event. Most likely, monetary form of money (i.e. currency, as opposed to the various intermediary goods) appeared almost simultaneously in the East and the West during the socalled Axial Age*, which encompassed the life of Buddha (623-543 BC), Confucius (551-479) and Pythagoras (570-495) (Graeber, 2011, p. 224). However, the real impact of the first money on globalization still differed. It could be concluded that one of the inherent qualities of premodern globalisation was the split of global money depending on the territory. The three sources of money (Hellenistic, Indian, and Chinese civilizations) for some time existed quite separately,

\footnotetext{
* Term «Axial Age» (from German «Achsenzeit») was coined by a German philosopher K. Jaspers in The Original Goal of History (1953, pp.1-25).
} 
as did their systems of economic exchange. Still, some of them remained an element of domestic economic activity and were later incorporated into the monetary systems of other origin (Indian and Chinese sources, albeit to different extents), while the Hellenistic source served as the foundation, and later the standard for monetary systems of various countries.

Thus, for the purposes of our research, we consider that money appeared on the edge of Europe and Asia, within the borders of the Hellenistic civilisation, and spread further East and West through:

- first of all, wars of conquest that ensured the territorial expansion of money both within the territory of the victors (Persia, Rome, Mongol Empire), and their new dominions,

- $\quad$ and the development of trade relations, which created opportunities for other nations to embrace the idea of money (firstly, along the Silk Road - Central Asia, India, China).

Nevertheless, it was state, and not the market, that was instrumental in the appearance of money. Moreover, the relationship of state and money proved so tight, that repoussé (issuance of money), according to $\mathrm{M}$. Weber (1978, pp. 963-965), became one of the principal reasons for state building from then on.

The gold coins of Lydian king Croesus («croeseids» or «kroiseioi stateres»), minted in $550 \mathrm{BC}$, can be considered the first international money. Confirmation of their international status was the fact that they were used as a means of payment by both the neighbouring Hellenic city-states (supplanting silver), and an entirely different civilisation - Persia. However, Lydia was at the crossroads of civilizations, so even from this point of view, gold money inexorably had international status. Unfortunately, the temporary or transitory status of Lydia and its demise in the war against Persians before the eastern expansion was ultimately stopped by the united fleets of Hellenic states spelled the end of the first (known) war for gold as a monetary unit.

Later, as we know, the Greeks were able to take revenge for their defeats. In $330 \mathrm{BC}$, after Alexander the Great defeated Persia, he managed to gather practically all the gold and silver available at the time (around 9 thousand tonnes). Therefore, in truth, the first global currency (on the territory of almost all known to the Greeks oikumene at least) was the Macedonian tetradrachm. However, after the death of the great general, the riches once again went to different kingdoms, overwhelmed the monetary exchange and caused the first inflation in the Mediterranean countries.

Therefore, it is considered that the Persian kings (Cyrus the Great and Darius I) and Alexander the Great started the perpetual motion of the monetary globalisation - the advance of one civilisation and counter-advance of another, by means of which money flows crossed the enforced and conventional 
borders, and furthered the creation of a single market space - step by step, era by era.

The Hellenistic age of monetary globalisation was characterised by the free circulation of foreign coins (a free convertibility of sorts) with the exception of Egypt, where the use of foreign coins was forbidden (Morawski, 2002, p. 23). Moreover, the first inter-civilizational (quasi-civilizational) clash had consequences for the money. The Greek monetary traditions (the so-called Indo-Greek coins) spread to Hindustan (which participated in the afore-mentioned clash only briefly) and practically superseded the dharmic monetary traditions.

Over the many centuries thereafter, the Hellenistic monetary traditions (model) spread to the west (within the Roman Empire) and to the east (within Persia), becoming an endogenous element of economic systems in both Christian and Muslim worlds. The development of inter-civilizational relations (Silk Road) facilitated a modernisation of the Chinese monetary system, which infiltrated the Euro-Asian space through Mongol conquests. The modernisation manifested as monetisation, in so much as the material form of money was concerned, although paper money was not used as the norm, but rather an «emergency» means of payment in China, even though it was undoubtedly invented there.

Therefore, many centuries ago, the three apparent leaders - silver, gold and paper - struggled over the monopoly on monetary functions. However, back then, there used to be large territories (the Americas, Africa), where monetary relations were still only at their inception and money as such did not yet exist. At the same time, the state pushed for the development of the monetary system and shaped it accordingly.

As a result, it can be argued that single (Western) European currency was established by Emperor Charlemagne. It was denarius or silver pence. As for Eastern Europe, in particular ancient Rus', the territories that withstood the Mongol invasion - Poland, Lithuania, Galicia, White Ruthenia - gradually integrated into the western European monetary space. Meanwhile, the principalities that became vassals to the Golden Horde needed silver to pay the tribute to the Mongol Khan, so they were forced to develop trade relations with countries that could supply it.

The process of chrymatogenesis (genesis of money) in the premodern times led to the emergence of Hellenistic monetary system. That is, the system that envisages the use of metal coins (mostly silver, sometimes gold) with officially fixed (or at least declared) content of the metal and value ratio of different monetary metals. They were considered a «legal means of payment» that was unquestionably accepted throughout the territory under the rule of the money issuer. They could also be used in other territories depending on the real content of the monetary metal and general demand through trade operations or free exchange into the local currency (metal convertibility). 
In general, the premodern monetary globalisation ended with the monetarisation of the Old World - the monetary system spreading and taking root in most of Eurasia (excepting the Far North and partially Siberia).

\section{Modern globalisation}

In the $14^{\text {th }}$ century China, the globalisation was stopped by the central government halting a successful start to maritime expansion and banning sea voyages, which was either a historical coincidence or a whim of a short-sighted administration. Meanwhile, in Western Europe, territorial dispersion of power and inter-state competitiveness promoted the search for new geoeconomic directions of development, which, in the end, allowed Christopher Columbus to find volunteers willing to risk and discover the New World.

This is also said to have been facilitated by the actions of «political Asia», that is Sultan Mehmed II, who captured Constantinople and stopped the trade along the Silk Road (which was the primary trade route for pepper and other spices, important goods of Middle Ages). This forced Europeans to seek alternate routes (Portuguese Prince Henry the Navigator sent expeditions around Africa; Columbus decided to simply cross the Atlantic Ocean, hoping to find India on the other side). Thus, Asia encouraged, or even forced Europe to lead further globalisation, starting its new stage - modern globalisation.

From the monetary point of view, the Europe-East monetary and trade relations were restored and intensified, while Europe-West relations were established for the first time. Thus, monetary globalisation reached entirely new territories in the course of the so-called Columbian exchange.

However, the list of all the good and the bad that went back and forth between the Old and New Worlds does not usually include money, even though the Columbian exchange had a tremendous effect on both hemispheres in terms of money. On the one hand, the every idea of money was first introduced to the New World (although notably the Spaniards managed to conquer only the coastal regions and other Europeans were not able to get deeper into Americas until the mid-late $19^{\text {th }}$ century, which curbed the territorial advancement of monetary relations). On the other hand, the New World supplied the Old with massive amounts of that same money in the shape of monetary metals: at first mainly silver, then - gold. The evident result of this was the unprecedented inflation caused by the depreciation of monetary metals.

Furthermore, the post-Columbian period transformed into the colonial era, during which new financial centres emerged. The Italian city-republics like Venice and Genoa were replaced by Amsterdam and London, commodity exchanges 
began to develop, and the first international crisis of a new level (Tulip mania) soon followed.

During the $16^{\text {th }}-18^{\text {th }}$ centuries, while the Europeans still only traded in Africa, they merely «infiltrated» the existent monetary system, for example accepting all local means of payment like cowrie shells (import of which from Maldives made up almost a third of all Western African import in 1720) (Fursov, 2016, p. 71).

However, as the colonisation deepened, the need to modernise the exchange system naturally emerged, thus requiring the introduction of a proper monetary system. Since there was no local money on the majority of the continent (excepting the Arab north), the India's example of modernisation was not viable and brand new introduction was necessary.

The modernisation of the monetary system in the East was even slower. In particular, there were various monetary systems used locally in late Middle Ages Japan, supplemented by paper scrips, the so-called "hansatsu» (Shizume \& Tsurumi, 2016, p. 4). In general, Japan used the Chinese model of copper coin exchange, not unlike many other countries of the region. It was in the $15^{\text {th }}-16^{\text {th }}$ century that the country started developing gold and, most often, silver mines, which created the conditions for the modernisation of the monetary system (Shizume, 2017, p.2).

As for the European contribution, it is worth noting that the Portuguese brought large quantities of European (mainly Spanish) coins to the East and even minted both their own coins and those imitating the local polities' coins there. The East India companies (both Dutch and British) acted in the same way, so it follows that the minting of coins by these companies was one of the factors that contributed to their acquisition of qualities similar to those of autonomous political forces (Fursov, 2016, p.68).

When considering the monetary globalisation in Asia, we must also note the events of the $16^{\text {th }}$ and later centuries in Siberia, when another new global exchange system took shape. After Yermak's conquest of Siberia, i.e. the colonisation of territories east of the Urals by the Moscow state, a process that we will call Yermak exchange started. In terms of monetary globalisation, we are interested in the introduction of the relatively modern (at the time) monetary system to the colonised territories, in exchange for the рухлядь (fur used as commodity money in Siberia and reasonably liquid "currency» in Europe) and, later, Siberian gold (which played an important role in Russia's shift to the Gold Standard in the late $19^{\text {th }}$ century).

In the meantime, after the fall of the Byzantium Empire, the Silver Standard spread through the world and remained prevalent until the $19^{\text {th }}$ century. Once France introduced the Franc germinal with a fixed ratio to silver and other European countries borrowed this system, de facto, a common monetary 
space was arranged through the market mechanism, rather than official agreements and administrative regulation. However, the discovery of a big gold deposit in California in 1850 and the subsequent influx of the yellow metal Europe experienced gradually led to errors in the market mechanism. For example, during 1852-1861 the average market ratio of silver to gold was 15.37:1 (Des Essars, 1896). Naturally, speculation boomed in such conditions, as per the Gresham-Copernicus' law. Due to this, the currency «balance» had to be restored through administrative measures.

Thus, silver was washed out of monetary circulation in the mid- $19^{\text {th }}$ century. On the other hand, the market was increasing saturated with gold, as a result of a series of gold rushes and booming mining of the yellow metal in Siberia, California, Australia, and South Africa.

The first clash of civilisations (which included two waves of globalisation) led to the creation of the colonial system and the spread of the European (Abrahamic) monetary traditions to other civilisations. The second wave of modern monetary globalisation exhausted itself in the contest of bimetallism and gold monometallism, which ended with the victory of the latter. This was caused by both subjective advantages and objective requirements of the world economy that was getting increasingly globalised. Next was the time to make use of this victory. Gold coins were in circulation in such large quantities that the majority of yellow metal production in California, Australia, Russia and later South Africa was used for minting. Additionally, more coins were privately owned than kept in central reserves, although the ratio varied based on the accumulation of official reserves: the ratio was 23:1 in 1815, while in 1892 - only 2:1 (Marfunin, 1987, p. 182).

In fact, the last quarter of the $19^{\text {th }}$ century was the time of economic internationalisation in Europe (e.g. elimination of trade barriers), which created the conditions for monetary integration for the first time. Some additional conditions were the result of money circulation regulation. For example, coins of old samples were disused in Switzerland and Italy, regional monetary agreements were concluded in Germany (which ensured the transition of the German Empire to a single monetary standard before the creation of the empire itself), and the British pound and French franc were gaining international significance (while the pound mainly spread throughout the British colonies, the franc was gaining popularity in Europe - Piedmont, Belgium, Switzerland, Italy). Therefore, the establishment of the Gold Standard internationally was a multi-step process and a result of gradual modification of international monetary system, rather than a product of diplomatic agreements at the Paris or any other conference (which is markedly different from the creation of the gold-dollar standard at the Bretton Woods Conference in 1944).

Thus, at the start of the $20^{\text {th }}$ century, the Gold Standard could be considered global. However, the victory of the gold standard could hardly be considered decisive. Firstly, the two or three decades of its existence in the devel- 
oped countries are hardly enough to cement its historical victory and make a claim for being the pinnacle of monetary evolution. Moreover, it should be borne in mind that in many (if not most) developed countries (except Britain) the gold standard did not exist in its full form (i.e., with one hundred percent metal reserve). At the start of the $20^{\text {th }}$ century, the actual reserves of the Reichsbank covered around $50 \%$ of the banknotes (as in Japan), while in France this number varied between 50 and 60 percent, same as in Austria-Hungary. At the same time, despite the huge gold reserves, Russia on the eve of the World War I was not even in the top three countries with a developed circulation of gold, falling behind France, Germany, the United States and Britain. Complaints of money shortages and poverty were heard everywhere in the country (Bugrov, 2015, pp. 65-66).

Secondly, the Gold Standard was not established everywhere, as large markets such as China, many Latin American countries, and much of Africa remained outside it. Although colonial trade was conducted with the gold currencies of the metropolises, the African population, for example in the north of the continent, demanded payment in Maria Theresa thalers (Europeans minted this defunct currency even in the early $20^{\text {th }}$ century, backdating it to 1780). At the same time, the local population on the rest of the continent did not even use coins en masse, but rather specific products-monetary surrogates of copper, which was the «red gold» of the «black continent». However, the colonies gradually introduced a system of «currency bureaus», and, for example, India (as well as Japan and some Latin American countries to some extent) de-facto used the gold exchange standard.

The spread of the gold standard marked, at the same time, the intensification of the interstate struggle for the status of international currency. Despite the British leadership in introducing a new monetary standard, the American currency gradually (since its inception in the $17^{\text {th }}$ century) edged the pound and the franc out. However, in the context of globalization, the creation of a global currency based on the old principles of the gold standard proved impossible. Therefore, in 1945 the rate of gold reserves for the Fed's issue of banknotes was reduced to $25 \%$, and in 1965 - abolished altogether. As J. Rueff aptly noted, the dollar remained convertible as long as no one demanded its convertibility. Nonetheless, attempts by France to convert the American currency into gold ingots immediately led to a crisis, the collapse of the Gold Pool, and soon - the closing of the «gold window» in 1971.

In the deep waters of economic phenomena, this process was reflected on the surface as the structural evolution of the global monetary system. Until the early 1970s, Western Europe was an integral part of the Bretton Woods system. However, the dollar crisis (caused, in part, by the policies of some Western European countries, and especially France), the collapse of the Gold Pool, the emergence of a two-tier gold market and, ultimately, the cessation of dollar-togold exchange for central banks - all this has forced EU governments to look for 
a safer harbour for their economies in a turbulent ocean of currency. The European Monetary System has become such a haven.

If we were to disregard the historical examples, it could be argued that the idea of European monetary integration was pioneered by Robert Mundell in his work The Theory of Optimal Currency Zones, published in 1961. In this article, he quoted J.S. Mill, who considered attempts by states to preserve their own currency barbaric and concluded that the «Balkanization» of monetary systems (i.e. the fragmentation of one large system into several small ones) makes it difficult for money to fulfil its main function - to make trade more convenient.

The significant increase in the number of countries subscribing to the Kingston monetary system due to the addition of post-soviet nations was another important change. A large group of countries with very specific features was created as a result of the collapse of the international socialist economic and monetary system, which was based on the principles of purely administrative regulation.

By and large, the development of the international monetary system in the post-Bretton Woods era essentially repeated the interwar scenario. There were attempts to restore the pre-war status quo ante (after WWI - the gold standard, after WWII - the gold exchange standard), but it became clear that gold (commodity) money could no longer meet the requirements and conditions of the global economy. This was expressed in the nationalization of gold, its concentration in the reserves of central banks and the establishment of an artificial official price (which, as M. Gilbert (1980) aptly remarked, was not a price set as value relative to supply and demand, it was the law). In the end, all these euphemisms and palliatives were abandoned and all ties between modern currencies and gold were severed.

\section{Conclusions}

In essence, this was the end of modern monetary globalization. The overarching discourse of global transition (globalist discourse) set the tone for the further development of monetary globalization. It excludes the idea of order as a necessary condition for understanding the world order (Sledzevskii, 2020, p. 84). A discourse that presupposed the existence of certain laws of world development (in terms of the British sociologist Z. Bauman $(2000,2001)$ a Joshua Discourse) is replaced by a discourse of instability, uncertain direction of development or (in terms of the same author) Genesis Discourse - the discourse of creating a new world order.

In this context, it can be argued that modern late-modernism of this process was shaped by the creation of the Jamaican monetary non-system (which al- 
lowed for the European monetary integration and its collective currency) and the inclusion of post-socialist countries into the international monetary system. This signified the return to market commodity-money relations of territories that had been previously encompassed by monetary globalisation, but fell out of the loop for a while because of the communist «experiment». This stage marked the end of the extensive phase of monetary globalisation (geographical expansion of monetary relations) and any further intensive development will occur through fundamental qualitative changes.

Historical analysis indicates that money played a significant role in the process of economic globalisation, in particular:

1) it contributed to the emergence of a general sense of economic activity by creating a single framework based on the measured value of manufactured products (goods), while the monetary expression of product value became the common economic language (economic lingua franca) used by different markets for communicative purposes;

2) it has become a universal tool for the development of trade and credit relations around the world, through the functions of circulation and payment;

3) last but not least, its role as a universal impetus (incentive) towards the search for new markets and resources, development of new trade routes, great geographical discoveries, economic integration and, finally, economic globalization itself.

All these processes occurring both at the level of individual national markets and small regions and at the international level (which money entered though its function of global currency from the outset) constitute the essence of monetary globalisation.

Looking back on monetary globalisation today, we can be state that metallic money was immanent to the premodern era and its dynastic (personal) sovereignty of monarchs and trade (exchange) economy. Modern era, with nationstates and industrial development, required fiat money (not tied to the value of the substance from which it is made). Finally, late-modernism with a global network of supra-sovereignty and a post-industrial economy requires even more flexible monetary systems based on digital information transfer technologies. 


\section{References}

1. Bauman, Z. (2000). Liquid modernity. Polity Press.

2. Bauman, Z. (2001). The individualized society. Polity Press.

3. Bugrov, A.V. (2015). Gold standard in Russia: choice of the path (1867 1897) [in Russian]. Russian Journal of Money and Finance, 1, 59-67.

4. Cohen, B.J. (1998). The geography of money. Cornell University Press.

5. Department of Geography. (n.d.). The economic geography of money and finance. University of Cambridge. https://www.geog.cam.ac.uk/research/ projects/moneyfinance/

6. Des Essars, P. (1896). Part VIII: The Latin Monetary Union. In Editor of the Journal of Commerce and Commercial Bulletin (Ed.), A History of Banking in all the Leading Nations; comprising the United States; Great Britain; Germany; Austro-Hungary; France; Italy; Belgium; Spain; Switzerland; Portugal; Roumania; Russia; Holland; The Scandinavian Nations; Canada; China; Japan; (Vol. 3, pp. 345-379). The Journal of Commerce and Commercial Bulletin. http://oll.libertyfund.org/?option=com_staticxt\&staticfile=show.php\%3 Ftitle $=2239$ \& chapter $=212158$ \&layout $=h t m|\&| t e m i d=27$

7. Fursov, K.A. (2016). Monetary propaganda of colonial empires in the AfroAsian world [in Russian]. Russian Journal of Money and Finance, 7, 67-73.

8. Gilbert, M. (1980). Quest for world monetary order: Gold-dollar system and its aftermath (P.M. Oppenheimer \& M. Dealtry, Eds.). John Wiley and Sons Ltd.

9. Graeber, D. (2011). Debt: The first 5,000 years. Melville House.

10. Lyzun, M. (2017). Global challenges of the regional monetary integration [in Ukrainian]. TNEU.

11. Marfunin, A.S. (1987). History of gold [in Ukrainian]. Nauka.

12. Martin, R., \& Pollard, J. (Eds.). (2017). Handbook on the geographies of money and finance. Edward Elgar Publishing.

13. Masson, P.R., \& Pattillo, C. (2004). The monetary geography of Africa. Brookings Institution Press.

14. Morawski, W. (2002). Reviev of the general history of money and banking [in Polish]. Wydawnictwo Trio.

15. O'Brien, R. (1992). Global financial integration: The end of geography. Council of Foreign Relations Press.

16. Shizume, M. (2017, October). A history of the Bank of Japan, 1882-2016. WINPEC Working Paper Series, E1719. 
17. Shizume, M., \& Tsurumi, M. (2016, September). Modernizing the financial system in Japan during the 19th century: National banks in Japan in the context of free banking. WINPEC Working Paper Series, E1607.

18. Sledzevskii, I. (2020). The civilizatonal dimension of modern world development: Problems and approaches [in Russian]. Mirovaya ekonomika $i$ mezhdunarodnye otnosheniya, 64(1), 82-90.

19. Weber, M. (1978). Economy and society: Monetary and financial presuppositions of bureaucracy. University of California Press. 